\title{
Social Security Policies in Connection with Sustainable Economic Growth in the Period 2011-2020
}

\author{
MAI NGỌC CƯờnG \\ National Economics University - cuong.ktpt@gmail.com
}

\begin{tabular}{|c|c|}
\hline ARTICLE INFO & ABSTRACT \\
\hline $\begin{array}{l}\text { Article history: } \\
\text { Received: } \\
\text { Dec. } 12,2013 \\
\text { Received in revised form } \\
\text { Jan } 24,2014 \\
\text { Accepted: } \\
\text { Sep. } 30,2014 \\
\end{array}$ & $\begin{array}{l}\text { The paper shows that the Vietnam's system of social security } \\
\text { policies during its reforms increasingly supports risk prevention, } \\
\text { mitigation and management, positively contributing to the } \\
\text { implementation of targets for human development. This system, } \\
\text { however, reveals many shortcomings, such as its limited coverage } \\
\text { and low impact on beneficiaries. Since the system, in which all } \\
\text { citizens are guaranteed to be engaged, should assure people's } \\
\text { fundamental needs and increase its scope of impact, greater } \\
\text { accountability of involved parties is required. Additionally, on the } \\
\text { basis of synchronous development of all components of the social } \\
\text { safety net, it is vital that the policy model, organizations in operation } \\
\text { and/or services and finance resources providers be diversified and } \\
\text { that the development of social security policies be attached to } \\
\text { economic and social development. }\end{array}$ \\
\hline
\end{tabular}

development. 


\section{PROBLEM STATEMENT}

Social security is a part of sustainable development. The development of social security system on the basis of social insurance, health insurance, unemployment insurance, and social benefits will ensure the aims of human and social development.

During the years of reform, Vietnam's social security system is increasingly developed. The social insurance, health insurance, unemployment insurance, and frequent and infrequent social benefits further expand positive impacts on people's lives and contribute to sociopolitical stability, especially during the economic crisis.

Nevertheless, improving social security in Vietnam's context faces such challenges as limited coverage and low impact, which affects the sustainable development of the nation. Social security policies in connection with sustainable economic development between 2011 and 2020, thus, arise as an urgent issue.

Based on secondary materials, CPV and State laws and policies as well as Vietnam's scientific studies, the paper performs an analysis of social security policies during the years of reform with data dating back to 2005 , demonstrates their growing impacts, and proposes solutions to the improvement of these as regards sustainable development until 2020.

\section{FACTUAL REALITY OF SOCIAL SECURITY POLICIES AND SUSTAINABLE DEVELOPMENT OF VIETNAM TODAY}

It can be confirmed that $\mathrm{CPV}$ has been concerned about the development of legislation on social security since its inception. To date Vietnam has had quite a sufficient system of legal documents that ensure social security, namely Social Insurance Law and Health Insurance Law, providing a solid legal basis for the operation of social security system. Accordingly, Vietnam's current social security system is composed mainly of the following constituents:

\subsection{Social Insurance Policies}

Prior to the introduction of Social Insurance Law, there was in Vietnam a single form of social insurance specifically for public-sector workers. As with the development of a multi-sector economy, the labor force working in the non-public sector has increased and changes have also occurred in social insurance. The 2006 Social Insurance Law constitutes the two types of social insurance: compulsory versus voluntary (Vietnam National Assembly, 2006). 
Compulsory social insurance is applicable to "Vietnamese employees who work under labor contract with definite term and contract of three months and more", and its benefits comprise: (i) sickness benefit, (ii) maternity benefit, (iii) labor accident/ occupational disease benefit, (iv) retirement benefit; and (v) survivors' benefit (Vietnam National Assembly, 2006).

Voluntary social insurance, before the Social Insurance Law, was implemented in several provinces, having typical applicability to Nghệ An's peasants (Mai, 2009). According to Social Insurance Law, as from Jan. 1, 2008, voluntary social insurance is applicable to employees who work in non-formal sector. Concerning the benefits, voluntary social insurance participants are entitled to: (i) retirement benefit; and (ii) survivors' benefit (Vietnam National Assembly, 2006).

\subsection{Unemployment Insurance Policy}

It was only implemented in Vietnam in 2009. Article 4 of the Social insurance stipulates that Unemployment insurance participants are entitled to (i) Unemployment allowance, (ii) Vocational training allowance, and (iii) Job-seeking allowance (Vietnam National Assembly, 2006).

\subsection{Health Insurance Policy}

This is carried out on a non-profit basis by the Government in the field of medical care. Article 12 of the Health Insurance Law names 25 groups of insured persons with corresponding premium. The law, in nature, tries to establish a universal heal insurance (Vietnam National Assembly, 2008).

\subsection{Social Assistance Policy}

Vietnam offers benefits to the needy, officially called beneficiaries of social benefits (Vietnam Government, 2007), comprising regular and irregular social benefits.

Regarding the regular social benefits, the policy on such benefits has been adjusted and improved many times since 1986. Guidelines on beneficiaries, policyimplementing agencies, and operating mechanism have been also issued. There have been so far 30 laws and ordinances, along with more than 200 documents made by the Government and various ministries to modify the social assistance.

Welfare is a principal part of the social assistance policy that is adjusted to socioeconomic conditions and budget income. In the 5-year period from 2005 to 2010 , 
the welfare threshold was adjusted twice, which serves as a basis for calculating welfare payments for different groups of beneficiaries (Vietnam Government, 2010).

Regarding irregular social benefits, they always attract great attention because Vietnam suffers many natural disasters (storms, floods, or droughts) every year. Besides support from communities, the policy on irregular benefits tries to protect livelihood and life of affected groups. This policy covers a wide range of groups of citizens, offers various classes of benefits, and is adjusted regularly to socioeconomic conditions to meet urgent needs of persons affected by unpredictable disasters.

\section{AN ESTIMATE OF IMPACTS OF SOCIAL SECURITY POLICIES ON THE SUSTAINABLE ECONOMIC DEVELOPMENT}

\subsection{Positive Impacts}

Social security policies during years of reform have improved the ability to prevent, alleviated or overcome risks, thereby giving more care to the people and aiming at the development for the people.

First, coverage of social insurance, health insurance and unemployment insurance is expanded. Regarding the social insurance, the number of participants rose from $2,275,998$ in 1995 to $10,576,502$ in 2012 , equaling $20.11 \%$ of the working population.

Although it was only introduced in 2009, the unemployment insurance attracted up to 8.3 million persons covering $66.4 \%$ of the workforce who were provided with compulsory social insurance.

The number of participants in health insurance program rose from 3.79 million in 1993 to 88.78 million in 2012. Its coverage increased from $28.0 \%$ in 2005 to $66.64 \%$ in 2012 (GSO, 2012; Đăng Kiên, 2012; Vietnam Social Security, 2012; Mai, 2009; Đỗ, 2011).

Second, the number of beneficiaries of social insurance and health insurance increased steadily. In 2007, 106,242 persons were included in the program provided with monthly social insurance, increasing the group of persons receiving monthly pension and allowance to 2.13 million; the group receiving one-time allowance to 204,063 persons; and the group receiving other kinds of allowance to 3.04 million. Retirement pension and welfare paid to 5.37 million persons amounted to VND33,711 billion while payments for consultation and treatment for 73.19 million persons rose to VND8,120 billion in the same year. 
Up to $2010,140,200$ more persons were included in the program provided with monthly social insurance, increasing the group of persons receiving monthly pension and allowance to 2.4 million; the group receiving one-time allowance to 635,267 persons; and the group receiving other kinds of allowance to 4.3 million persons. Retirement pension and welfare paid to 7.35 million persons amounted to VND64,000 billion; unemployment allowance paid to 149,100 persons was worth VND460 billion, and payments for consultation and treatment for 106.9 million people rose to VND19,002 billion.

In 2012, the Vietnam Social Security increased the retirement pension and welfare immediately after the Government increased the minimum wage level (Vietnam Social Security, 2012).

Third, coverage of the regular social benefits program was expanded while the irregular social benefits program attracted more attention from the Government. In 2010 , some 1.5 million persons became eligible for community regular benefits. This figure is some 10 time higher than 2000 and 3.12 time higher than 2005 ones.

\subsection{Shortcomings}

Besides these achievements, the implementation of social security policies reveals many shortcomings.

Poor coverage of health insurance: Up to 2012, only $20.11 \%$ of the population of the age of 15 and above were included in this scheme, and most of them work in formal sector that enjoys the compulsory social insurance.

Poor impact of social insurance: The present retirement pension can only ensure food and accommodation for retirees while their greatest need is health care, and they cannot afford necessary treatment when suffering serious health problems.

Limited coverage of social benefits programs: These programs cover only $1.5 \%$ of the population and $9.22 \%$ of population eligible for such benefits (Department of Social Protection, 2010) while this figure in neighboring countries varies between $2.5 \%$ and $3 \%$ (World Bank, 2010).

Although the range of beneficiaries of social protection policy has widen, it fails to cover all vulnerable groups (NA Committee for Social Affairs, 2012). In 2013, foundlings and orphans with no allowance or guardians represented $76.5 \%$ of children of this group; $72.6 \%$ of the disabled received no monthly welfare payments; and 
$33.64 \%$ of old-aged persons without guardians received no old age pension (Department of Social Protection, 2013).

At present, the minimum welfare payment for beneficiaries living in communities only equals $17.14 \%$ of average personal income; $30.23 \%$ of average personal spending; or $40 \%$ of poverty threshold for rural area promulgated in 2011 . In short, it could cover only part of basic needs for the beneficiaries. Moreover, intervals between adjustments to level of welfare payments are usually long (from three to five years), the minimum payment cannot reflect beneficiaries' basic needs and cost of living. In the 2000-2010 period, this threshold increased by 2.7 times while the CPI rose by 4 times (NA Committee for Social Affairs, 2012).

In implementing the policy, welfare payments were not given timely to beneficiaries in remote and mountainous districts. Many beneficiaries knew nothing about their interests. Public nursing houses have been built in most provinces, but the private sector and communities did not take part in such activities.

Poor coverage of irregular social benefits: It is limited to persons affected by natural disasters and fails to give aid to those who are affected by socioeconomic risks. The average size of benefits can cover only $10 \%$ of losses per family. Authorities fail to mobilize and coordinate support from non-public sectors or communities.

\section{CAUSES OF SHORTCOMINGS}

\subsection{Inadequacies of Social Security Policies}

The retirement age set by law is obsolete while Vietnam's life expectancy has become higher, which lengthens the time the retirees enjoy their pensions (to 19.4 years on average). Regulations about early retirement are not strict enough with the result that the number of early retirees rose quickly (at present, some $60 \%$ of workers accepted early retirement).

There are inequalities between compulsory and voluntary social insurance: (i) Those two insurance policies apply the same contribution rate (22\% at present) but buyers of the compulsory insurance are partly financed by their employers while buyers of voluntary insurance (most of them are peasants) receive no financial aid; (ii) When income of peasants and workers in non-formal sectors is lower than the minimum wage rate, using the latter as a basis for calculating the contribution rate is unreasonable; (iii) Buyers of compulsory insurance may receive insurance payments in 
five cases (illness, retirement, maternity, labor accident/occupational disease, and death) while buyers of voluntary insurance get payment in only two case (death and retirement); and (iv) Buyers of compulsory insurance can have their retirement pensions adjusted to the minimum wage rate if their pension is lower than the minimum wage rate while buyers of voluntary insurance are denied such treatment.

Sanctions against violations of the Law on Social Insurance are not severe enough: low fines and interest rate on arrears of premium payments lower than bank lending rate fail to prevent appropriation of premium payments; and regulations about authority to handle such violations are not appropriate.

Legal normative documents relating to implementation of social insurance policy, such as regulations about hospital fees, bidding for supply of medicines, participation of private persons in supply of health care services, consultation and treatment for the elders and undersixes, etc., are not reasonable and in harmony. Mechanism for managing the health insurance fund is not effective enough to prevent embezzlement and deficit. Relevant authorities could not control prices of medicines, and quality of consultation and treatment services in healthcare institutions in provinces. Lack of regulations about violations in health insurance business leads to misuse of health insurance fund.

Definition of beneficiaries of regular social benefits is too strict to be applied with the result that many needy groups cannot benefit from this policy.

\subsection{Factors Affecting the Implementation of Social Security Policies}

Changes in structure of urban and rural population take place slowly. Up to 2007, proportions of urban population and rural one were $27.44 \%$ and $72.56 \%$ respectively. These figures in 2010 were $27.99 \%$ and $72.01 \%$ and they are expected to be $29.03 \%$ and $70.97 \%$ by 2015 (Mai, 2009).

Shift of labor from agriculture and non-formal sector to formal sector is also slow. Proportions of labor in non-formal sector and formal one were $27 \%$ and $73 \%$ respectively in 2007. These figures in 2010 were $30 \%$ and $70 \%$ and they are expected to be $35 \%$ and $65 \%$ by 2015 . Agricultural labor accounted for $52.8 \%$ of the working population in 2007 and $48 \%$ in 2010 and may fall to $40 \%$ by 2015 .

Proportions of the elders and children tend to rise. Ratio of the elders (60 years old and above) to population was $9.27 \%$ in 2007 and $9.82 \%$ in 2010 and it is expected to rise to $10.07 \%$ by 2015 when Vietnam could be considered as a country with an "old population." 
Ratio of children to the population also rose steadily, from $11.74 \%$ in 2007 to $12.3 \%$ in 2010 and may reach $13 \%$ by 2015 (Mai, 2009).

Generally, changes in structure of population and workforce at present and in the future may become a challenge to the development of the social security system, regardless of what principle it is based on (contribution/ entitlement or non contribution).

\subsection{Poor Coordination in Implementation of Social Security Policy along with other Social Policies}

First, policies on wage and income do not harmonize. The premium for social and health insurances is based on salary, yet the minimum salary is still kept at a low level at present. In administrative and non-profit sector, additionally, income and salary are much different because the real income of workers in this sector is 3-4 times greater than their nominal salaries (Mai, 2012); therefore, the premium paid by the insured to social security fund is still small although it, as a percentage of their salaries, is not low.

Second, the combination of social security with policies on poverty reduction is not yet close when they are implemented by many public agencies and organizations, leading to an overlap between beneficiaries and a poor use of resources. Policies on poverty reduction tend to provide the poor with cash or support in kind instead of helping them achieve or improve their sustainable livelihood. Moreover, although education support policies provide various kinds of financial aids for students from poor families, expenditures covered by the family for education for their children are still high compared with their income.

Third, although number of participants in compulsory social insurance and health insurance increase over years, many enterprises are reluctant, or fail, to buy such policies for their workers. Avoiding or owing payments for social insurance and health insurance is widespread in non-public sectors. The number of participants in voluntary health insurance is still small. As for near poor families, they can hardly buy voluntary health insurance policies though provincial authorities cover up to $50 \%$ of the premium, and in some case, district authorities give them an additional $30 \%$ of the premium.

Fourth, coordination of social security system with supply of basic social services shows many inadequacies. The system of social services in rural and remote regions is still quantitatively and qualitatively poor. Only $46 \%$ of communes have health centers of national standards, $11.7 \%$ of communes have no kindergartens and nursery schools while schools for students of all levels, especially in mountainous districts, are poor 
built. Rural and remote districts lack doctors and teachers; and if any, most of them are not well trained and facilities for their operations are simple and of poor quality.

The proportion of ethnic minorities getting access services is much lower than people of Kinh and Chinese origin. The majority of rural residents have to use unclean water and suffer poor sanitary conditions. Many communes included in Program 135 could not finish infrastructure building plans. In addition, opportunities for vulnerable groups, especially poor migrants in cities and ethnic minorities, to access social services are also slim. Moreover, commercialization in social service supply increases social inequalities between groups of citizens.

Participation of private sector in social service supply is very limited. There is a lack of professional social workers; and no criteria and policies on wages and benefits for social workers.

Last, the social insurance fund suffers overspending despite all efforts to control investment from the fund and use of the fund, which damages stability of the social security based on contribution-entitlement principle. Due to polices on encouragement to near poor households to buy voluntary health insurance, contribution to the social security fund increased from VND13,035 billion in 2009 to VND25,540 billion in 2010, which reduced overspending to VND2,300 billion. Yet, the deficit was estimated at approximately VND9,776 billion in 2011. This implies that social security fund based on contribution-entitlement principle may collapse without support from the national budget (Department of Social Protection, 2010).

\subsection{Inadequacies of Organization and Staff Competence}

First, regarding social insurance, regulatory compliance of employers and employees is limited, and the role of trade union in enterprises is not fully developed to protect legitimate and legal rights of employees. Lawsuits relating to arrears of insurance premium payments are time-consuming and have not been solved positively. Legal basis to solve the lawsuits is not firm enough, and therefore legal action taken as a measure to deal with avoidance of premium payments does not produce satisfactory results. Moreover, the coordination between different authorities in implementing the social insurance policy is not regular. Some provincial governments are reluctant to apply sanction against enterprises that avoid premium payments because they want to attract investment projects. Implementation of the unemployment insurance policy is also difficult because it requires joint efforts from various agencies. 
Second, in implementing the health insurance policy, there is no incentive to apply more advanced and effective payment methods in order to save costs and raise the efficiency of fund use. Health establishments do not pay full attention to management of health insurance fund. Tasks of storing and granting medicines and medical equipment are poorly organized. Installation of modern and expensive medical equipment in hospitals by private investors is usually manipulated by interest groups and become one of hot topics in many provinces. Controls over consultation and treatment services are not strict enough. There are not enough officials specializing in medical fee review and many of them lack necessary expertise while managers of health insurance service in many provinces fail to monitor operations of their subordinates.

Third, lack of an inter-agency coordination in planning, allocating budget and giving instructions on implementation of social assistance policy causes difficulties in mobilizing resources. Administrative procedures and decision making process are complicated. State control, supervision, reporting and evaluation are poor. Tasks of gathering data, making lists of possible beneficiaries at district level are not done properly with the result that reports are not made regularly and many needy people are not included in the assistance program.

Current network of social protection agencies is quantitatively and qualitatively poor. Facilities of these state-run agencies are not adequate and majority of their personnel are not trained in social work. Non-state social protection agencies attract no attention from authorities and also face difficulties in terms of facilities, personnel and training.

Supply of irregular benefits after natural disasters, in many cases, is not timely and fair or reasonable. Tasks of propagating methods of avoiding and preventing labor or road accidents are not carried out properly, and effectiveness of such efforts are low.

\subsection{Poor Organization of Social Security Machinery}

The social security machinery organized and run by the state may help realize such targets as social equality, and solidarity and integration of different communities. This machinery, however, also proves to be inflexible and unsuited to market economy, causing great burdens on national budget expenditures.

At present when social insurance policies are arranged into social insurance and voluntary and compulsory health insurance laws, peasants and workers in the nonformal sector find it difficult to buy such insurance policies. Mai \& Phan (2012) find 
that only middle-class or rich families can engage in the contribution/entitlement social security system. Phan (2012) also finds that peasants can spend only VND13,000 on voluntary social insurance and other VND10,000 on health insurance every month while the contribution rate set by law is much higher than these figures. As a result, although these laws came into effect for three or four years and some subsidies are offered to potential buyers, only $2 \%$ or $3 \%$ of workers in agriculture and non-formal sector bought voluntary social insurance and $20 \%-30 \%$ of them bought voluntary health insurance. It could be concluded that such mechanism is ineffective.

The non-formal sector and agriculture in Vietnam are employing some 33 million workers (equaling some $60 \%$ of the working population) out of 66 million residents in rural areas. Giving subsidies to help them buy voluntary health and social insurance requires a huge fund, which may become a burden on the national budget and produce an inequality when national budget income is used for help a part of population take part in a social security system based on contribution/entitlement principle. In other words, helping poor workers to engage in social security may help reduce a social inequality but using national budget income to do so create a new inequality. It is a vicious circle for social security authority.

\section{POLICY RECOMMENDATIONS}

The aforementioned analyses show that the social security policy in connection with Vietnam's sustainable development in 2011-2020 should be oriented toward the following targets:

First, government has to help all people participate in the social security system. All citizens need protection in order to live, work and take part in social activities. Their needs for food, shelter, clothing, sanitation, education, healthcare, study, and job, etc. in their daily life as well as in times when they face social upheavals or natural disasters should be satisfied.

At present, although the social security system has improved, it could not meet all people's needs. This implies that its coverage should be expanded according to either contribution/entitlement principle or non-contribution principle. The social security system, therefore, should have various layers including social insurance, health insurance, and unemployment insurance as required by law; regular and irregular social benefits; and policies on minimum support for people affected by disasters. 
Second, social security system should be improved in both directions: to satisfy basic needs of participants and to increase its impacts on beneficiaries. Accordingly, this effort may aim at two targets:

(1) Building social protection floor as an initiative proposed and organized by the International Labor Organization and the World Health Organization with cooperation from $17 \mathrm{UN}$ agencies and accepted by the UN in April, 2009. The objective is to clearly determine scope of programs, beneficiaries, level of assistance and plans to ensure that financial support from the national budget may be enough to implement the social protection floor effectively.

(2) Along with the social protection floor, it is necessary to enhance impacts of social security by improving policies on social insurance and health insurance. The system of social security should ensure the workers, when they become old and/or retire, can live on their retirement pensions, and pay for medical care and other essential needs of life.

To achieve this aim, policies on salary need to be reformed. Currently, income of workers in the public sector and administrative machinery is often much higher than their nominal salaries, which are used as a basis for calculating their premium payments to social insurance funds. As a result, low contributions lead to low retirement pensions. Salaries should be high enough for workers to support themselves, their families and their life after retirement, and therefore, all of sources of income outside the payroll should be added to their salaries to raise their contributions to the social insurance fund. This is a decisive measure to increase social security benefits.

\section{SOLUTIONS PROPOSED TO IMPROVE SOCIAL SECURITY SYSTEM AND SUSTAINABLE DEVELOPMENT IN 2011-2020}

First, accountability of all involved parties should be strengthened. Social security is not necessarily some grant given to a beneficiary but a legal right protected by law. However, social security rights need be perceived with two connotations: beneficiary's rights and participant's accountability, i.e. not only do people have right to be entitled to social security system but they have responsibility to be engaged in the system through individual contributions and accumulation.

Employers have right to protect their labor force and also have responsibility to contribute to social security system as the law stands.

The State itself has the right to ensure social security for all of its citizens while taking over financial responsibility to support and raise people's living standards through social and health insurance programs. 
At present, rights and responsibility of all participants in social security are not fully comprehended. Evasion of paying premiums of social insurance, health insurance, and unemployment insurance is relatively common among enterprises, especially non-public and even FDI ones. Public expenditures on social benefits programs are still low, equaling approximately $0.12-0.14 \%$ of GDP in the years $2008-09$, whereas in such other developing nations as Mexico or Brazil the rate ranges between $0.3-0.5 \%$ of GDP. This requires that expenditures of public budget need be restructured with a view to increasing its proportion allocated to social benefits programs, poverty eradication and labor market development. By that way, social security network may successfully be constructed.

To guarantee all citizens' social security rights accordingly, accountability of all participants in the system should be enhanced. The implementation of social security policies is the duty of all classes; it is vital that: (i) joint efforts by individuals, families and enterprises to make contribution to the system be strengthen, (ii) State's responsibilities for social benefits programs be reinforced, and (iii) loyalty, solidarity, coordination, and support among individuals, social groups and the State be encouraged. Following that, social security both assure people's fundamental needs via mobilization and reallocation of resources and little by little enhance the impact, the roles as well as meanings of social security implementation to participants.

Second, by connecting all components of social security network such as social insurance, health insurance and social benefits, poverty alleviation and development of labor market; authorities can diversify sources of finance, management and supply of basic social services such as education, health care, clean water, and environmental sanitation. Connection and mutual support among social security forms should be ensured. Development of social security system should be closely associated with the administrative reforms in all of the three aspects: policy-involved institutions, organization-involved institutions, and financial institutions.

Third, as social security is a part of social policy system, there should be a close coordination between social security and implementation of other plans of social policies. Thus, this practice can promote the role and effects of each policy which bolsters up the overall impact of the social policy system and moreover, overcomes overlaps between plans, ensuring efficient implementation and various resources use.

Last but not least, developing social security system has to be based on improved economic and social development. Since the development of social security, as perceived 
here as a stage of redistribution of wealth, must be consistent with certain conditions of socioeconomic development, there cannot be a sound and modern mode of distribution and redistribution while the level of development is still low. The foundation of social security must be built on socioeconomic background of a particular country, which requires Vietnam to carefully plan an appropriate formation of social security. A social security system within a sustainable development requires a balanced socioeconomic development that aims at increasing both personal income and budget revenue as a basis for a social security system with various funds and levels of risk prevention, mitigation, and management. All social members are subsequently benefited from minimum or above minimum social security, avoid impoverishment, and have ability to fulfill all duties associated with their rights

\section{References}

BVPL (2013), "Báo động tình trạng nợ bảo hiểm thất nghiệp" retrieved from baohiemxahoi.gov.vn/?u=nws\&su=d\&cid=384\&id=8265 on Oct. 29,2013

Department of Social Protection (2010), Số liệu bảo trọ xã hội và giảm nghèo giai đoạn 2006-2010, Lao động-Xã hội Publisher.

Department of Social Protection (2013), "Báo cáo kết quả tổng số đối tượng sống tại cộng đồng năm 2013".

Đăng Kiên (2012), “Tổng kết, đánh giá 3 năm thực hiện Luật Bảo hiểm y tế" retrieved from http://bhxhthanhhoa.gov.vn/portal/news/Hoat-dong-cua-nganh/Tong-ket-danh-gia-3-nam-thuchien-Luat-Bao-hiem-y-te-402/ on Oct. 29, 2013.

Đỗ Văn Sinh (2011), Đề án đánh giá hoạt động Quỹ BHXH, BHYT; tính toán dụ báo cân đối Quỹ BHXH, BHYT đến năm 2020 và tầm nhìn đến năm 2030, BHXH Việt Nam Publisher.

Mai Ngọc Cường (2009), Xây dựng và hoàn thiện hệ thống chính sách an sinh xã hội ở Việt Nam, Chính trị Quốc gia Publisher, Hà Nội

Mai Ngọc Cường (2012), "Về chính sách tiền lương và thu nhập ở nước ta hiện nay", Kinh tế và Phát triển, No 181 (July).

Mai Ngọc Cường \& Phan Thị Kim Oanh (2012), “An sinh xã hội theo nguyên tắc đóng - hưởng đối với nông dân ở nước ta: Thực trạng và khuyến nghị”, Kinh tế và Phát triển, No 185 (November).

NA Committee for Social Affairs (2012), "Báo cáo kết quả phiên giải trình của Bộ trưởng Bộ Lao động Thương binh và Xã hội về chính sách, pháp luật bảo trợ xã hội tại Ủy ban về các vấn đề xã hội” downloaded from http://www.na.gov.vn/htx/Vietnamese/default.asp?sAction=DETAIL_CONT\&intDocID=1762\#EcTC3au JohEI on June, 1, 2014. 
Phạm Ngọc Linh \& Nguyễn Thị Kim Dung (2008), Giáo trình Kinh tế phát triển, Đại học Kinh tế quốc dân Publisher, Hà Nội.

Vietnam Government (2007), “Nghị định 67/2007/NĐ-CP” retrieved from http://vanban.chinhphu.vn/portal/page/portal/chinhphu/hethongvanban?class_id=1\&mode=detail \&document_id=22662 on Feb. 20, 2014.

Vietnam Government (2006), "Nghị định 152/2006/NĐ-CP” retrieved from http:/vanban.chinhphu.vn/portal/page/portal/chinhphu/hethongvanban?class_id=1\&mode=detail\&docum ent_id=18935 on Feb. 10, 2014.

Vietnam Government (2007), “Nghị định số 67/2007/NĐ-CP” retrieved from http://vanban.chinhphu.vn/portal/page/portal/chinhphu/hethongvanban?class_id=1\&mode=detail \&document_id=22662 on Feb. 10, 2014

Vietnam Government (2009), "Nghị định số 62/2009/NĐ-CP” retrieved from http://vanban.chinhphu.vn/portal/page/portal/chinhphu/hethongvanban?class_id=1\&mode=detail \&document_id=89474 on Feb. 15, 2014.

Vietnam Government (2010), “Nghị định số 13/2010/NĐ-CP” retrieved from http://www.chinhphu.vn/portal/page/portal/chinhphu/hethongvanban?class_id=1\&mode=detail \&document_id=93348 on Feb. 15, 2014.

Vietnam Government (2012), "Nghị quyết 70/NQ-CP” retrieved from http://www.chinhphu.vn/portal/page/portal/chinhphu/hethongvanban?class_id=2\&mode=detail \&document_id=164350 on Feb. 15, 2014.

Vietnam National Assembly (2006), "Luật số 71/2006/QH11 của Quốc hội: Luật bảo hiểm xã hội” retrieved from http://chinhphu.vn/portal/page/portal/chinhphu/hethongvanban?class_id=1\&_page=1\&mode=detail\&do cument_id=28955 on Feb. 25, 2014.

Vietnam National Assembly (2008), “Luật số 25/2008/QH12 của Quốc hội: Luật Bảo hiểm y tế” retrieved from

http://www.chinhphu.vn/portal/page/portal/chinhphu/hethongvanban?mode=detail\&document_i $\mathrm{d}=81142$ on March, 13, 2014.

Vietnam Social Security (2012), "Báo cáo kết quả thực hiện chính sách bảo hiểm xã hội năm 2007 2011 và định hướng nhiệm vụ đến năm 2015”, Hà Nội. 